\title{
"The Care of the Poor Is Her Profession": Hannah More and Women's Philanthropic Work
}

\section{DORICE WILLIAMS ELLIOTT}

\author{
Department of English, The Johns Hopkins University
}

$I^{n}$ $\mathrm{n}$ an 1841 letter to William Ellery Channing, critic and historian Lucy Aikin noted that the practice of visiting the poor had now become "a fashion and a rage" among English women, thanks in large part to a novel published in 1808 by Hannah More, the famous Evangelical writer, philanthropist, and educator (Aikin 396). The novel was entitled Coelebs in Search of a Wife.' Aikin credits More and her fellow Evangelicals with originating a major shift both in the moral "tone" of nineteenthcentury society and in the role of women:

This philanthropic impulse acted at first chiefly within the Evangelical party; but that party became, at length great enough to give the tone to society at large; and the practice of superintending the poor has become so general, that I know no one circumstance by which the manners, studies and occupations of Englishwomen have been so extensively modified, or so strikingly contradistinguished from those of a former generation. (397)

Writing eight years after More's death and more than thirty years after the publication of More's educational works for women, Aikin identifies the kind of women's volunteer philanthropic work that More promoted and practiced as the distinguishing trait of the women of England.

By the time of Aikin's letter, the charitable labors of More's Lucilla Stanley and Lady Belfield, the heroines of Coelebs in Search of a Wife, seemed a natural part of the role of middle- and upper-class women. Countless mid-nineteenth-century Englishwomen visited hospitals, prisons, workhouses, and the homes of the poor on a regular basis. ${ }^{2}$ Given the almost universal acceptance of the ideology of separate spheres that confined women's activities to the home and family, these charitable endeavors constituted their one opportunity to participate directly in the larger world outside their homes. Even though it took women out of their homes and onto the streets or into institutions that housed some of society's worst problems, philanthropic work seemed acceptable because it was viewed as an extension of women's domestic role. Middle-class women, it was believed, could use their knowledge of domestic economy to reform institutions and to "superintend" the lives, homes, habits, and attitudes of the poor. As envisioned by both More and Aikin, women's philanthropic work was vital both to women themselves and to the security and sta-

Nineteenth-Century Contexts, 1995

Vol 19, pp. 179-204

Reprints available directly from the publisher Photocopying permitted by license only
(1) 1995 OPA (Overseas Publishers Association) Amsterdam B. V. Published under license by Gordon and Breach Science Publishers SA Printed in Malaysia 
bility of society because it was a way of relieving the distress that could lead to unrest and of instilling "correct" values in the laboring classes.

While many of the historians and literary critics who have studied the history of women and their roles have noted that women participated in philanthropy because it was an extension of their domestic role, very few have offered any explanation of how this assumption came to be made. In fact, charity is not a "natural" extension of women's domestic role; rather, the connection between charitable and domestic work was, like many other assumptions about gender roles, the result of specific historical factors. As Aikin recognized, the works of Hannah More were key to the process of naturalizing philanthropy as a part of women's domestic role. In her conduct books, novel, and tracts, More took the upper-class woman's traditional "Lady Bountiful" role that had served to reinforce paternalism's hierarchical bonds of deference and refashioned it to suit the new social, political, and economic conditions of her time. Because she rejected the language of the marketplace, More seemed to react against the capitalist economy that was coming to dominate England; her new-styled paternalism, however, used philanthropy's gift economy to replicate capitalism - without seeming to. Preserving and expanding well-to-do women's part in philanthropic activities, More assigned them a crucial role not only in maintaining harmonious class relations, but also in fuelling a consumer market. Instead of using the language of the marketplace, however, More drew on the rhetoric of Evangelical reform and the conventions of conduct-book literature-not only to reinforce "strictures" of female propriety, but also to stimulate women's rational desires for increased public usefulness through broadly-defined charitable activities. Thus, while on the one hand More's works upheld domestic ideology's prescription for women, on the other they posed an inherent challenge to that ideology's confinement of women within the private sphere of the home by making their participation in publicly useful activities outside the home seem to be simply an extension of their domestic role.

Despite the crucial part that More played in redefining women's roles in nineteenth-century England, only recently have scholars begun to take account of the cultural import of her writings. Like Lucy Aikin, historians Leonore Davidoff and Catherine Hall credit More with "setting the terms for the characterization of domesticity and sexual difference" (149), while Mary Poovey notes More's role in placing women on "the Victorian pedestal" (33). Mitzi Myers uses social anthropology to "carefully disinter" the strategies of reformist women like More during the turbulent 1790s ("Reform" 202). She explains how More reinterpreted domestic culture in order to provide active roles for women, defining domesticity in terms of social responsibility and casting political questions as moral and religious problems that women could solve ("Reform" 204; "Tracts" 273-4). Thus, Myers maintains, More's program of "aggressive virtue" made her "a female crusader infinitely more successful than [Mary] Wollstonecraft or any other competitor" ("Reform" 209).

Like Myers, a number of other recent historical critics have focused on the new possibilities opened for women by More's revision of domesticity. Responding to Myers, Elizabeth Kowaleski-Wallace claims that More's program for women was a 
strategy for displacing anxiety about her own body. Although Kowaleski-Wallace acknowledges More's influence on nineteenth-century ideas about women's roles, she argues that any gains that More achieved for herself and other women were secured only through her complicity with patriarchy and were hence "tragically inadequate" to the task of freeing women from the dictates of patriarchy (93). Kathryn Sutherland and Christine L. Krueger, on the other hand, place More in a tradition of women writers whose works extended the possibilities for women through their domestic role. The feminized familial domain that More's writings promote, Sutherland argues, "cut[s] through a bankrupt patriarchal model of social relations" (46). Emphasizing More's connection with a tradition of women preachers, Krueger maintains that "[More] intends to teach women how to gain access to social discourse and demands that men repent of their efforts to exclude them" (113). While Myers, Sutherland, and Krueger recognize that philanthropic work was a key component of the "aggressive virtue" that More felt would reform society, none of these critics explains how naturalizing female philanthropy as part of domesticity not only rewrote the terms of paternalism but also helped to generate ambitious desires that posed a challenge to the domestic ideology that "good works" were supposed to support and extend.

Even more recently, Beth Fowkes Tobin has focused specifically on More's version of philanthropy. Tobin casts More as a spokesperson for the rising middle class against the land-holding gentry and aristocracy who had "abdicated their paternal responsibilities" to the rural poor (3). Middle-class women, writes Tobin, filled the void left by the abdication of the masters with their charitable labors. More was "confident that women of the middling classes, who had mastered the microtechnologies of self-regulation, could change the hearts of the poor, teaching them to accept with humility and gratitude their place in the paternal order" (123). While it is certainly true that More criticized the landowning classes for their moral laxity and neglect of responsibilities, I maintain that her goal was to reform, not replace, the aristocracy; in fact, as I will argue, Coelebs in Search of a Wife represents reformed aristocratic women as the most influential exemplars of domesticity and the most important practitioners of philanthropy. And, though she did portray a societal model based on paternalistic ties, More's version of paternalism was not merely a return to an idealized past, but was rather a new paternalism that could accommodate and serve a consumer-driven market economy and could be administered by both middle- and upper-class women.

More's refashioning of paternalism depended on the traditional association of women of the landed classes and charitable activity. While well-born landlords exercised power over their social inferiors through their control of property and the legal system, the "Lady Bountiful" figure also had an acknowledged and socially important role in maintaining the hierarchically organized relations between different classes of people that characterized traditional rural paternalism. ${ }^{4}$ Women of the landed classes had typically visited and aided the poor on their estates and in the surrounding villages, overseen and taught in charity schools, and donated money for hospitals and almshouses. Their expenditure of time, money 
advice had been crucial in maintaining the bonds of deference that tied laborers to the land and its owners. ${ }^{5}$

The eighteenth century, however, had seen important changes in the organization of society that challenged these traditional bonds. An evolving capitalism, both industrial and agricultural, steadily pushed (or attracted) laborers away from the small villages and into larger towns and cities. Harold Perkin points out, for instance, that by 1801 only about a third of English families were engaged in agriculture, while a far larger number worked in trade, manufactures, and commerce (31). With neither physical proximity to nor traditional ties with urban laboring people, women of the landed classes had little contact or influence with them. Further, along with these changes in the distribution of the population had come new methods for dealing with the poor, the sick, and the unfortunate that implicitly devalued the informal social contributions of wealthy women.

One key innovation in eighteenth-century philanthropic practice was the introduction of charitable subscription societies (Gray $\mathrm{x}$ ). Modelled on joint-stock ventures, charitable subscriptions were marketed like stock, and many societies were managed like commercial enterprises, with a director, a body of governors, and weekly committees (Gray 273; Owen 12). Thus the financing and administration of charitable work took on more and more of the language and practice of the male-identified world of business and politics. Even clergymen employed language identified with political discussions and the marketplace to describe charitable activities, finding "spiritual significance in joint-stock companies" and noting that money "invested" in charity would bring "a dividend in the improved happiness and morality of the poor" (Clarke 23).

Charitable subscription societies welcomed women as subscribers and some had begun to rely on women to distribute the funds and do much of the actual work of philanthropic projects. Despite this material reliance, however, charitable institutions that proposed business-like solutions to social problems tended to exclude women from active roles as directors or leaders. By reclaiming a Lady Bountiful-like role for both upper- and middle-class women, More's writings worked to restore women to active leadership in charitable endeavors, both institutional and non-institutional. Thus More's oft-disparaged commitment to paternalistic social relations was more than simply patriarchal complicity or a political blindspot; it was a fundamental and necessary condition of the "profession" she claimed for middleand upper-class women - the profession that was to give them access to the public sphere outside their homes (Coelebs 2: 20). ${ }^{6}$

More, whose Evangelical agenda included a new and more central role for women, held tenaciously to what seems like a traditional paternalistic social order based on the mutual responsibilities of rich and poor. Women, through their superintendence of the poor, were both vital to the functioning of this imagined social order and dependent on it for their own sense of usefulness and authority. More's strong belief in a paternalistic system is particularly evident in one of her most explicitly political pieces for the Cheap Repository Tracts, "The Riot: Or, Half a Loaf Is Better Than No Bread, In a Dialogue Between Jack Anvil and Tom Hod," 
which is actually credited with having stopped a riot near Bath (Harland 176-77). One of the arguments steady Jack uses to counter Tom's democratic sentiments is that "the gentlefolks" will help out during bad times. As in traditional paternalism, More's rich have as strong a moral obligation to help the poor as the poor have to work for the rich. The solution Jack offers in this ballad to the problems attendant on "bad times" is not, however, that landlords will take care of tenants and tenants of laborers in a hierarchical system of interlocking responsibility; instead he imagines that the rich will fulfill their obligations to the poor by subscribing to organized group charities. The "gentlefolks" will help by giving up "their puddings and pies" in order to subscribe to charities (Works 1:260).

The modification of traditional notions of paternal responsibility that Jack expresses in More's ballad was necessitated by the breadth of the current distress-not only were too many of the poor "displaced," or not attached to any particular estate or village, but also (presumably) there were too many in need during such times of crisis for individual landowners to supply. While a Lady Bountiful might have succored the poor on the family estate in times past, More now calls on subscription societies to meet a more widespread need. But, as More implies throughout her published works and through the example of her own philanthropic career, she expects women to maintain what had been their casual and unofficial role as dispensers of charity even in new and more public forms of philanthropy. Thus More relies on a traditional version of paternalistic values but adjusts them to current problems in such a way that she can retain and even enhance the role that women play in handling the problems of the poorer classes. Unlike the traditional system, however, women need not be rich to act the role of charitable lady, because their contribution involves managing more than merely dispensing charity.

That women's philanthropy means much more in More's view than merely dispensing food and blankets to distressed individuals is especially evident in several of her tracts addressed to "persons of the middle ranks" (Works vol. 4). In these pamphlets, More gives specific instructions and practical advice aimed at teaching women with little money how to reform their communities. In "A Cure for Melancholy" (4: 325-357), the newly impoverished widow Mrs. Jones manages to work a reformation in people of all ranks in the parish in which she lives, even though she has no money to contribute herself. ${ }^{7}$ Mrs. Jones's story, some of it based on Hannah More's own first-hand experiences in charitable work, is a model of the kind of charity More advocated for her new Lady Bountiful.

On the advice of the vicar Mr. Simpson, Mrs. Jones sets out not to give monetary assistance, but to educate the poor of the parish where she has come to live and motivate them to reform what she sees as their bad habits. For instance, she convinces the local women to avoid tea and white bread and butter (which are both expensive and inappropriate to their station in life) by teaching them to cook more appetizing meals, bake their own (coarser and cheaper) bread, and brew their own beer, which keeps their husbands away from the public houses and contributes to temperance-which yields better laborers. In her visit to inspect the local charity school, Mrs. Jones teaches the girls to cut and sew, mend, wash, and iron, thus mak- 
ing them better potential servants. Through her skill at explaining their duties to others, she effects other reforms as well: she manages to prevent a dishonest baker from selling substandard loaves of bread (by instructing a local butcher in the merits of becoming an "informer"), to arrange for fresh milk and dairy products for the poor without jeopardizing the profits of large-scale dairymen, and to get villagers to boycott a shop that does business on Sunday. She convinces the gentry to buy only the more expensive cuts of meat so the poor can make soup from the poorer cuts, instigates the closing of all but two (necessary) public houses, and institutes a Sunday School. Thus almost singlehandedly Mrs. Jones manages to solve the most pressing problems of the parish thraugh her philanthropic educational efforts.

Through Mrs. Jones, More also outlines her vision of reformed paternalist relations. As Mrs. Jones explains to the vicar (and the reader, whether poor or rich):

Providence, in sending these extraordinary seasons of scarcity and distress, which we have lately twice experienced, has not only excited the rich to an increased liberality, as to actual contribution, but it has led them to get more acquainted with the local wants of their poorer brethren, and to interest themselves in their comfort; it has led to improved modes of oeconomy, and to a more feeling kind of beneficence. Above all, without abating any thing of a just subordination, it has brought the affluent to a nearer knowledge of the persons and characters of their indigent neighbours: it has literally brought the rich and poor to meet together.... (356)

The lesson that the rich need to relearn, in More's view, is the value of the face-to-face contacts with the poor that paternalism formerly was supposed to ensure. "The extraordinary seasons of scarcity and distress" of the 1790s were, as More's readers were well aware, also seasons of extraordinary fear of working-class unrest and even revolution. Her antidote is to maintain "a just subordination" through active, local charity that mimics old-style paternalism in a new situation in which the affluent no longer have a "near knowledge of the persons and characters of their indigent neighbors." This is to be accomplished, of course, through women like Mrs. Jones, whose influence in the community eases conflicts between the various classes and teaches all-characters and readers-to do their Christian duty to each other.

This technique of educating her more affluent readers through texts ostensibly addressed to those beneath them is used frequently in the stories and ballads More wrote for the Cheap Repository Tracts. The tracts, which were initially printed below cost in order to compete with (or, rather, it was hoped, to supplant) vulgar ballads and chapbooks and seditious pamphlets by Paine and others, ${ }^{7}$ were marketed directly to the poor through hawkers, but also to persons of higher rank (at a higher price than hawkers paid) for free distribution to the poor. They were read by people in every class, including the king, who "expressed his delight openly" (Harland 172-73). By 1796, the tracts were being published on cheap paper for sale by hawkers and on better quality paper and in bound editions for the gentry, many of whom bought them for their children or their own libraries (Spinney 303). Thus the tracts had a multiple audience: both the poor to whom they were explicitly addressed, and those who in a sense read over their shoulders. This enabled More to provide 
lessons not only to the poor in how to do their duty and to live happily within their means and station, but also to instruct their "betters" in their responsibilities to the poor. By representing the concerns, customs, dialect, and attitudes of the poor, the tracts themselves actually helped to accomplish More's aim of teaching her middleand upper-class readers to understand "the persons and characters of their indigent neighbours."

When More addresses the landed classes explicitly, she clearly invokes a traditional paternalistic vision of a society held together by interlocking bonds of duty and interest. Coelebs in Search of a Wife, for instance, is a conduct book written in the form of a novel explicitly in order to reach readers who were affluent enough and likely to buy novels or frequent circulating libraries (Jones 193). The main characters, like those of most sentimental novels, are either aristocrats or gentry, and like the poorer characters in the tracts, are meant to serve as either negative or positive models of the behavior More would like to inculcate. For persons at this level of society, who do have landed estates, More's aim is partly to reawaken their sense of their paternalistic responsibilities. Mrs. Stanley, for instance, explains how "subordination" can be "just." "Surely," she says, "the reason is particularly obvious, why the bounty of the affluent ought to be most liberally, though not exclusively, extended to the spot whence they derive their revenues" (2: 22). "There seems indeed to be a double motive for it," she declares:

The same act involves a duty both to God and to man. The largest bounty to the necessitous on our estates is rather justice than charity. "Tis but a kind of pepper-corn acknowlegement [sic] to the great Lord and proprietor of all, from whom we hold them. And to assist their own labouring poor is a kind of natural debt, which persons who possess great landed property owe to those from the sweat of whose brow they derive their comforts, and even their riches. (2: 22)

Making justice and charity synonymous makes it possible for the rich to feel morally upright and equitable without redistribution of wealth or destruction of social hierarchies, while it benefits the poor by giving them a claim on the bounty of the rich. As long as the rural laboring classes can be made to adhere to a "just subordination," even during periods of distress like that of the 1790 s, the rich will owe them the "natural debt" that theoretically holds the classes together.

Even in her works for the landowning classes that seem to uphold a traditional version of paternalism, however, More invokes a slightly different vocabulary that works to redefine, or modernize, paternalism. This redefinition constitutes More's most significant contribution to early-nineteenth-century discussions of social and economic relations. In Coelebs, for instance, Charles, the hero of the novel, speaks to the Stanleys's lame gardener, who details all the kind things Lucilla and her family have done for him. The gardener thus ends his recital: "At Christmas they give me a new suit from top to toe, so that I want for nothing but a more thankful heart, for I never can be grateful enough to God and my benefactors" (2: 53). While some of the kindnesses of the Stanleys evidently work to fulfill their "natural debt" to their dependent, this final instance, the Christmas suit, is a gift in excess of debt because it creates an unrepayable debt: "I never can be grateful enough." This language labels 
the favors of the rich as charitable gifts rather than as "natural debts." The charitable gift to the poor creates a sense both of obligation and of insufficiency in the recipient. Defining the bounty of the rich as charity confirms a set of relations based on a gift economy, as described by anthropologist Marcel Mauss, rather than as an employer/employee relation characteristic of an emerging market economy.

Mauss specifically identifies the gift exchange system of primitive societies with alms-giving, or, in other words, charitable giving (15). What distinguishes the gift economy from a market economy, says Mauss, is that in the gift exchange system the objects exchanged take on moral and spiritual value. The most important of these "spiritual mechanisms," he writes, "is clearly the one which obliges us to make a return gift for a gift received" (5). There is in addition in a gift exchange system an equally important obligation to accept a gift that is proffered. Thus those who are unable to repay a gift in kind must still accept it, but they must repay it in other ways, such as service and gratitude. ${ }^{10}$ If, like the lame gardener, one can never be grateful enough to repay the gift, then one must not only work for the giver, but also behave with deference toward the benefactor and allow the benefactor to superintend one's life, as well as one's work. While this relationship between benefactor and the object of charity resembles traditional paternal relations, in More's program it applies not only between landlords, their Lady Bountiful wives and daughters, and their dependents, but also between middle-class women like Mrs. Jones and the poor with whom she has no obvious connection besides the fact that she pays them charitable visits.

According to Peter Blau, who applies Mauss's observations to a capitalist society, the dual obligation to receive and to repay a gift "makes it possible for largess to become a source of superordination over others, that is, for the distribution of gifts and services to others to be a means of establishing superiority over them" (108). Lucilla's charity, then, is a gift that marks her generosity, but it is also a way of establishing superiority and power over those "beneath" her, as well as changing the meaning of the exchange of goods and services between them. The gardener, as an employee on the Stanley estate, receives pay for work done, and, under the terms of a market economy, he could be seen as a "free" agent exchanging his labor for a wage. By extending charity towards him, the Stanleys displace the market system with a gift economy that obligates the gardener and makes his labor insufficient as a repayment for goods received." Thus the "economy of charity," based on the type of gift exchange in which there is a "unilateral supply of benefits," makes the poor or laboring-class recipients of philanthropy "obligated to and dependent on those who furnish [these benefits] and thus subject to their power," whether the poor are dependents on a rural estate or urban laborers (Blau 112). Of course, if women are the primary agents in charitable giving, this way of defining their activity puts them in a position of considerable power and authority over those they "serve"-a position they would not normally hold in customary market exchanges.

In order to fill and maintain this position of power and authority, women thus need for the poor to remain poor. This may explain at the most basic level why 
women (and also, to some extent, men) committed to helping the poor through philanthropy were also committed to maintaining a paternalistic, gift-based social system..$^{2}$ Commenting on what had happened in women's philanthropy during the nineteenth century, Lucy Aikin wrote that "a positive demand for misery was created by the incessant eagerness manifested to relieve it" (90). While More was genuinely committed to improving the lot, both spiritual and temporal, of the lower classes, she was equally convinced of the need to keep the poor in their places (both literally and figuratively), to teach them to be content with their situation (and not to work to raise their social status), and to urge their gratitude toward their benefactors. As long as there were poor to be educated and relieved, there would be work-and authority-for charitable women.

Thus, while the philanthropic act could fulfill the poor person's need, it was necessary at the same time to generate a new need, which would require another philanthropic act. Accordingly, once children were taught to read in the Sunday Schools, they needed appropriate reading materials-i.e., Cheap Repository Tracts. Or, once a child learned to read, as does Hester Wilmot in the companion tract to "The Cure for Melancholy" and "The Sunday School" (Works 5: 283-331), the parent develops a desire to read, which requires an evening school for adults in addition to the Sunday School or charity school. Hence, while in More's system charitable acts displace market exchanges between employers and laborers, at the same time philanthropy expands according to the same logic as capitalism.

Ultimately, of course, many of the working-class people who took advantage of philanthropic programs, especially schools, did eventually develop desires that could not be filled by philanthropic ladies, but instead led to the very things More was trying to prevent-labor unions, universal suffrage, etc. ${ }^{13}$ That that possibility was built into the very idea of educating the poor is evident in More's often-noted unwillingness to teach writing in her schools. Says Mrs. Jones, echoing statements made elsewhere in More's own voice (Jones 3),

I do not in general approve of teaching charity children to write. ... I confine within very strict limits my plan of educating the poor. A thorough knowledge of religion, and of some of those coarser arts of life by which the community may be benefited, include the whole stock of instruction, which, unless in very extraordinary cases, I would wish to bestow. (Works 4: 352)

Mrs. Jones treats the poor with respect and rails against those who "think that any thing is good enough for the poor" (Works 4: 353), but that the poor remain poor is absolutely necessary to her whole endeavor-which, in her case, as a single widowed gentlewoman, is the only endeavor available to her. In a way, she needs the poor far more than they need her-hence her (and her author's) reliance on a system like the gift economy that obliges (or hopes to oblige) the poor to receive her charity because every gift (or philanthropic act) generates an insufficiency, a need for another gift (or philanthropic act).

Along with the implied power that philanthropy gives to the benefactor in More's vision of an ideally functioning society comes the right and responsibility of the philanthropic woman to superintend those she relieves. Not only does philan- 
thropy create an unrepayable obligation, it also gives to the upper-class woman the right to supervise the household of the poor. One of Lucilla's major philanthropic projects, for example, involves her orchard and garden. When one of the servants or a girl from the charity school marries-"provided they have conducted themselves well, and make a prudent choice" (2: 48) - Lucilla "presents their little empty garden with a dozen young apple trees, and a few trees of other sorts, never forgetting to embellish their little court with roses and honeysuckles" (2: 50). This, recollects Charles, explains the "many young orchards and flourishing cottage gardens" in the village, which "embellish poverty itself" (2: 52), rendering it pleasing to the eye of the tasteful rich. Besides pleasing their aesthetic sense, these flowers, though transplanted to the gardens of the poor, still evidently belong to the rich-another characteristic of a gift exchange economy. ${ }^{14}$ Charles cuts a bouquet of roses for Lucilla from the bush outside the cottage of one of "her poor" without even mentioning it to the inhabitants of the cottage present in the room (2: 278). And Lucilla, Charles learns, makes "periodical visits of inspection [to ' $h e r$ poor'] to see that neatness and order do not degenerate" (2: 52).

Such gentle coercion, which not only teaches but forces the poor to "do their duty," is "well-becoming the tenderness" of the female sex, says More (Strictures 7: 135). Ladies should "consider the superintendence of the poor as their immediate office," she explains, because

They are peculiarly fitted for it; for from their own habits of life they are more intimately acquainted with domestic wants than the other sex; and in certain instances of sickness and suffering peculiar to themselves, they should be expected to have more sympathy; and they have obviously more leisure. (135)

This sympathetic superintendence, then, extends not only to the charity school and the home, but even to the most intimate details in the lives of the poor. Despite (or perhaps partly because of) the fact that the sexual functions of their own bodies are unmentionable ("certain instances ... peculiar to themselves"), philanthropy gives upper-class women the opportunity to oversee even the sexuality of the lower classes, thus firmly maintaining the existing social and political structure at its most basic levels. ${ }^{15}$

More's revised paternalism, based on the exchange of gifts and obligations and requiring the services of women as the agents of charity to and supervision of the lower classes, also participated in and reacted against a boom in the consumer economy. According to historian Neil McKendrick, consumerism reached "revolutionary proportions" in the third quarter of the eighteenth century: " $[M]$ en, and in particular women, bought as never before" (9). This new ability to spend, while uneven, spread at least to a certain extent across virtually all classes, rather than being confined to the affluent as it had been in previous ages. Even those in the lower ranks wanted and were occasionally able to purchase clothing, furniture, and food that had traditionally been available only to the well-to-do, even if such articles were cheaper imitations. During this period, many in England began to realize that the social emulation that spurred consumerism was productive of economic growth because it spurred trade (McKendrick 15). But, explains McKendrick, "[T] he un- 
leashing of the acquisitive instincts of all classes still posed too great a threat" to many observers, because "self-improvement through spending implied genuine social mobility" (McKendrick 16). ${ }^{16}$

More's writings show that she shares this anxiety about the breakdown of social distinctions through the poor emulating the rich by eating the same foods, wearing the same clothes, etc. As we have seen, a large portion of Mrs. Jones's efforts in "The Cure for Melancholy" were to convince those she was attempting to "help" that it was more economical for them to eat foods appropriate to their station: home-baked dark bread, rather than white; home-brewed beer rather than purchased spirits; fresh meat (of poorer cuts) instead of butter; and, most of all, milk or water instead of tea. Tea, in fact, was for many, including the famous eighteenthcentury philanthropist Jonas Hanway, "the apotheosis" of "needless extravagance by the poor" (Mathias 162). As More phrased it, for the poor to give up these luxurious practices and eat home-prepared food suitable to their station would be one step towards restoring the "good old management" (4: 342). Yet Mrs. Jones's advice to the poor on these particular subjects should not be read as a rejection of the growing consumer economy, but rather as a redirection: if the poor practice domestic frugality by spending less on (healthier) food, they will become capable of supplying more and better labor and they may have more to save toward less perishable goods (like Cheap Repository Tracts). Mrs. Jones also contributes to the smoother functioning of trade by teaching local small storekeepers to respond to customer demand for milk by keeping their own cows-which facilitates the largescale sale to urban markets of dairy products produced on local farms (4: 348). Thus, the charitable activities More proposes for women through the example of Mrs. Jones do, in a sense, work both with and against the growing consumer economy. In fact, though More definitely opposed widespread social mobility, social emulation was in some ways the mainspring of her theory of reform because emulation registered the influence of the upper classes. Such emulation on the part of the poor, however, when it involved tea and white bread-and the idleness that supposedly went along with "taking tea"-was also a source of anxiety.

More's ideal woman philanthropist also participates in a consumer economy through her own role as consumer. In More's family-based philanthropic scenario, husband/male-philanthropist accumulates money through investments and/or rents; the wife/female-philanthropist puts the money back into the economy by spending it, ${ }^{17}$ and by enabling the poor to spend. In More's scheme, women's philanthropy facilitates this gendered circulation of money both indirectly and directly. Lucilla, for example, rather than denying her own pleasures, "imposes on herself" an act of charity with each "personal indulgence" (2:51). "From this association she has acquired another virtue," she smilingly tells Dr. Barlow, the clergyman:

[S] he is sometimes obliged to content herself with practicing frugality instead of charity. When she finds she cannot afford both her own gratification, and the charitable act which she wanted to associate with it, and is therefore compelled to give up the charity, she compels herself to give up the indulgence also. By this self-denial she gets a little money in hand, for the next demand, and thus is enabled to afford both next time. (2: 51$)$ 
In this situation, Lucilla practices both frugality, the hallmark of domestic economy, and philanthropy at the same time, while also disciplining her own desires. She is the perfect female consumer: her father's (and soon her husband's) money, dispersed both frugally and wisely, goes directly into the larger economy when she spends on "personal indulgences," and indirectly when she gives it out to the poor in acts of charity.

The charitable economic activities of Lucilla are contrasted in Coelebs in Search of $a$ Wife with the example of Lady Melbury. Rich and beautiful, Lady Melbury squanders her large allowance at the gaming table, behavior that forces her to leave her creditors unpaid. By chance, Lady Belfield brings Lady Melbury to the home of one of the victims of her vice, a lovely young woman named Fanny. Fanny, whose tradesman father died in debtor's prison for a debt of the same amount owed to him by Lady Melbury, lives on crusts of dry bread while tending her dying mother who is paralyzed from a stroke brought on by her husband's arrest (1:147-8). Horrified at the consequences of her own profligacy, Lady Melbury repents of her vices, and, like Lady Belfield, is converted to domestic economy and the proper administration of philanthropy.

Coelebs, the novel that is continually searching for examples of perfect wives, ends with this conversion of Lady Melbury (there is only one chapter, summarizing Charles's later activities, following the description of her turn-around). Her case, one among many in the long two-volume novel, is given so much weight because she represents the woman at the top of the social scale. Addicted to gambling, high fashion, and other forms of dissipation, Lady Melbury has committed almost all of the female sins identified throughout the book (except adultery, which would prevent her final reclamation)..$^{18}$ She has defrauded her creditors, ignored the plight of the poor on her own estates, and dispensed charity to affecting cases from feeling and sensibility rather than the "pure motive" of glorifying God. Further, her charity has done little good because it was applied indiscriminately, without the supervision or "management" that should be directed toward the lower classes. Her philanthropy has been a vice of self-indulgence rather than a virtue with proper religious and political force; though it has had some economic effect, its impact even there has been limited because she has not taught the poor to spend their money to best effect. As Charles observes, however, "[A]s Lady Melbury had been the 'glass of fashion,' while her conduct was wrong, I hoped she would not lose her influence by its becoming right" (2: 412).

One major aim of More's conduct writing, in fact, is to promote Charles's hopeto convince high-born ladies like Lady Melbury to follow in her footsteps. The example and active philanthropic efforts of women of the higher classes would serve to disseminate the principles of domestic economy and proper philanthropy throughout all classes of women, thereby creating a reformed social order based on, but not identical to, traditional paternalism..$^{19}$ Although such principles have been associated with the rising middle class, More attempts to inculcate them in women of the landed classes as well, because her vision of a reformed society involves marrying the paternalistic bonds of the landed order with the values of the middle 
classes, particularly the Christian values of the Evangelical reform movement. Central to the accomplishment of this vision are exemplary women of all classes, teaching each other and men. But, as Lady Melbury's story indicates, More hopes that aristocratic women who have reformed themselves and learned to administer charity properly will lead the way.

In Strictures on Female Education, More specifically condemns the kind of charity initially practiced by Lady Melbury. In More's system, virtues that rise out of Rousseauvian sensibility are "almost more dangerous than the vices" (1: 36).$^{20}$ In language that perfectly describes Lady Melbury, More complains that "The chief materials out of which these delusive systems are framed are characters who practice superfluous acts of generosity while they are trampling on obvious and commanded duties" (1:36-38). Even the ideal Lucilla is tempted to perform charitable acts out of sentiment instead of as part of her devotion to God and the mission of reforming those she aids. Charity done for its own sake or rather, charity that is performed in response to a feeling of pity in order to generate a feeling of self-satisfaction, is both "crude" and selfish (2: 105). While clearly charitable and benevolent feelings, including pity, are Godlike and necessary to philanthropic endeavors, for More such emotions seemed uncomfortably close to the kind of indiscriminate and sentimental philanthropy that counterfeits Christian charity but leads neither to God nor to reform.

Besides its use as "the substitute of every virtue" and "the sponge of every sin" (1: 36-38), sentimental charity is directly linked to at least three sins: theft, by defrauding creditors; vanity, through the display of "dazzling" acts; and sensuality, since its "paroxysms" are motivated by "object[s] that affect the senses" (1: 36-38). It was extremely important to More to distinguish between what she saw as proper philanthropy and the kind of charity that resulted from such sensual and vain benevolence, particularly because the two might be mistaken for each other. In fact, it was specifically to counteract the novels of sensibility that promoted such unChristian acts of charity that More undertook to write her own novel. Coelebs in Search of a Wife, though short on plot and incident, provides not one but many positive and negative models of Christian charity-but without the heart-rending stories of distressed victims or the exquisite feelings of pity and its relief in pleasure from the act of charity that characterize so many sentimental novels. ${ }^{21}$ The charitable acts of the characters in Coelebs are meant to instruct women in pursuits that will extend their opportunities for usefulness, not to elicit their emotions. In other words, More's unsentimental novel substitutes disciplined, rational desires for the self-indulgent, sensual desires that had long been attributed to women.

Unlike one who sentimentally indulges in showy philanthropic acts, the woman who exercises charity properly does not compliment herself on her benevolence or sensibility, but sees herself only as the "underagent of Providence" (Coelebs 1:3). Fulfilling such a role is not only her duty, but also the reward of duty. More's new woman must also be on guard against taking too much pleasure in charity. Lucilla Stanley enjoys charitable activity so much that she worries it may be sinful-that 
she is doing it from her own natural desires rather than for the glory of God. For More, this kind of sentimental charity indulges the sensual. Her view resembles that of Thomas Malthus when he compares the benevolent impulse to sexual excitation: both, he observes, are "natural passions excited by their appropriate objects" (qtd. in Owen 98). According to More's program, women are to subdue any "natural" desires by directing them toward God. However, both Coelebs in Search of $a$ Wife and More's conduct books work to generate another kind of desire in both women and men. While More denies women sensual pleasures, she offers them authority and a kind of power, which specifically reinforce the behaviors necessary to a Christian version of the emergent capitalist economy. Thus, as long as desires for such power are kept in line with promoting God's glory, More encourages them. Page after page is devoted to representing the advantages to be gained for women from repressing their sensual desires and acting on their more ambitious (if selfless) ones. ${ }^{22}$ At the same time, by making the central character of her novel a young man searching for a wife, More attempts to create male desire for her new ideal woman by demonstrating to male readers the benefits of having such a wife, instead of a wife who indulges in sensual pleasures or exhibits showy accomplishments. Lucilla, the wife Charles finally chooses, exemplifies More's ideal so thoroughly that even her charity is rational and God-like, rather than impulsive and emotional.

While More distrusts the sensual attractions of sentimental charity, however, she also uses the implicit connection between sexual excitation and benevolent urges to make women essential to charitable projects, be they informal, or by implication, institutional. ${ }^{23}$ Throughout Coelebs in Search of a Wife, men, like women, participate in philanthropy, but only by giving money, usually for the women to distribute. Seeing the touching distress of the young woman ruined by the careless economy of Lady Melbury, Charles puts his purse into Lady Belfield's hands, "declining to make any present [him]self" (1:149). Charles declines to make his gift personally for fear he "should incur the suspicions of the worthy clergyman" standing by, who has just explained that he "reckoned [Fanny's] beauty among her misfortunes" because it made "good people afraid to take her into the house, and exposed her to danger from those of the opposite description" (1:149). By characterizing upperor middle-class men's charity as sexually threatening to victimized women, More makes direct philanthropic efforts by men dangerous, leaving the field open for middle- and upper-class women, whose sexuality presumably has been concealed under the label of "modesty." ${ }^{24}$ It is Lady Belfield who uses the money Charles contributes to rescue Fanny and restore her to a respectable situation. By representing even the charity of the exemplary Charles as a potential sexual threat, More guarantees middle- and upper-class women's place at the center of philanthropic activity, but only at the cost of suppressing their own desires for pleasure, even pleasure in performing benevolent deeds. Instead, More counsels, their desires should be directed towards pleasing God and reforming society according to His plan, a plan that accords women a more major role in managing society than do earthly political systems. 
Charity performed for the sake of pleasure, like charity performed for praise, also smacks of vanity, that "ubiquitous" vice which "is on the watch to intrude every where, and weakens all the virtues which it cannot destroy" (Coelebs 2: 106), because taking pleasure in charity is a kind of display to oneself. ${ }^{25}$ Benevolence "set at work by vanity," says Mrs. Stanley, is iniquity-"the iniquity of holy things," which "requires much Christian vigilance" (2: 23), because it is so insidious. Nonetheless, with "much Christian vigilance," women's charitable impulses can be turned to the "holy charity" that is the sign of true religion. That accomplished, then Christianity itself, for More, can be gendered feminine: ${ }^{26}$

Christianity indeed does not so much give us new affections or faculties, as give a new direction to those we already have. She changes that sorrow of the world which worketh death into "godly sorrow which worketh repentance." (Strictures 7: 178; my emphasis)

Using "her" feminine "affections" and "faculties" to perform acts of holy charity, Religion (through the bodies of women) exercises "her" power to "work repentance," or, in other words, to reform society.

In keeping with More's general insistence on religion as the only proper basis for charity, Mrs. Stanley, the model wife and mother in Coelebs, comments that the noblest charity is that which "cures, or lessens, or prevents $\sin$ " (2: 26):

And are not they the truest benefactors even to the bodies of men, who by their religious exertions to prevent the corruption of vice, prevent also, in some measure, that poverty and disease which are the natural concomitants of vice? $(2: 26-7)$

While Lucilla insists on religious motivation as a necessary condition for proper charity, in Mrs. Stanley's formulation, overt religious instruction is also an essential component of proper charity, not only because it will save the souls of its recipients, but also because it will in itself lead to improvements in their physical conditions. Although they are to provide pecuniary assistance where necessary, converting the poor from lives of vice and indigence is the more valuable form of service for More's exemplary women. Providing relief from distress, of course, is what sentimental charity usually does. In response to the sensation of pity, the giver acts to remedy the situation. But true charity, responding not merely to feelings of pity but to a call from God, seeks not only to remedy the current distress, but to work a change in the individual, the family, and in society at large-a change of heart which convinces the object of pity to accept uncomplainingly his or her "God-given" place in the social order.

More's emphasis on religion as key to her vision of a reformed society was not only a function of her own Evangelical beliefs. Christianity in England had long offered roles to women that extended beyond or offered alternatives to their domestic duties. For both members of the established Church and dissenters, almsgiving was an essential part of Christianity, a duty and a means to salvation. Not only did scripture enjoin women, like men, to emulate Christ through charitable almsgiving but Catholicism had left a legacy of "Sisters of Charity" whose primary occupation 
was practical philanthropy. While England had no sanctioned religious sisterhoods after the dissolution of the monasteries under Henry VIII, the existence of European sisterhoods kept the idea of women living together for the purpose of performing acts of charity alive, and proposals for secular or Anglican sisterhoods of various sorts, primarily for wealthy upper-class women, appeared in both seventeenth- and eighteenth-century England. ${ }^{27}$ Various dissenting groups, notably the Quakers, had long offered women a key role in administering charitable works. The religious association of women and charitable works was thus another important historical precedent for More's project of reclaiming the Lady Bountiful role in a time when capitalist individualism was replacing traditional paternalistic bonds.

In claiming philanthropy as a natural and necessary part of women's domestic role, More built on women's traditional roles both as Lady Bountiful and Sisters of Charity. Her promotion of women's philanthropy for women of the middle, as well as the upper classes, worked to extend what seems to be a narrow domestic prescription, and to assign it an importance that was both parallel to and part of the political and economic realms that were associated with men. Through her representations of women performing systematic, rational philanthropy, attended with authority over and gratitude from the poor, More hoped to motivate women of both the upper and middle classes to repress their "natural" sensuous desires and replace them with desires to become publicly, as well as privately, useful and powerful. In order to represent the kind of world she imagined, in which women's philanthropy would play such a crucial role, her conduct book writings call into play two conflicting vocabularies that enabled her to rewrite not only traditional paternalism, but also the public market.

While it supported the behaviors essential to the emergent capitalist economy, More's rewriting of charity gave these behaviors a significantly different emphasis. This emphasis appears in the vocabulary by which More describes philanthropy. While male writers often used the vocabulary of politics or the marketplace to describe philanthropic ventures, domestic writers, including More, more often characterized women's charitable activity in terms of domestic values. For example, in a preface to her political pamphlet "Remarks on the Speech of Mr. Dupont," addressed to the "Ladies, \&cc. of Great Britain," More links charity with two other virtues of her ideal woman, modesty and domestic frugality:

Even your young daughters, whom maternal prudence has not yet furnished with the means of bestowing, may be cheaply taught the first rudiments of charity, together with an important lesson of oeconomy: they may be taught to sacrifice a feather, a set of ribbons, an expensive ornament, an idle diversion. And if they are on this occasion instructed, that there is no true charity without self-denial, they will gain more than they are called upon to give. for the suppression of one luxury for a charitable purpose, is the exercise of two virtues, and without any pecuniary expense. (Works 6: 268)

If mothers teach their daughters to avoid vanity and display, and to practice domestic economy, the daughters will save enough money to contribute to charity. However, by attaching a preface that urges women to "relieve distress" to a political pamphlet, More links women's domestic values-charity, modesty, frugality-directly to politics and 
national security, and, indirectly, to the economic exchanges of the marketplace. By frequently urging the example and charitable activity of domestic women as a cure for urgent social and political problems, More implicitly makes the home the controlling metaphor for all human activity, including the state. ${ }^{28}$

If, in More's view, domestic values are appropriate to the wider world outside the home, domestic organization also has a wider application. The ideal home that More represents in Coelebs in Search of a Wife is an example of the kind of domestic arrangements described by Nancy Armstrong, in which the man provides the income, but the woman is responsible for transforming "a given quantity of income into a desirable quality of life" (Armstrong 84). By the early nineteenth century, this domestic organization was beginning to be mirrored in philanthropic practice, where women turned men's pounds not only into food, medicine, and advice for the poor on their estates, but also into schools, hospitals, asylums, properly run prisons, and tracts. ${ }^{29}$ Because men tended to use the vocabulary of business and politics to characterize these philanthropic projects, women like More could also call on this vocabulary to describe their "domestic" part in the undertaking. Hence More calls charity a woman's "profession" or her "trade." Says Mrs. Stanley, the model mother in Coelebs.

I have often heard it regretted that ladies have no stated employment, no profession. It is a mistake. Charity is the calling of a lady; the care of the poor is her profession. (2: 20 ${ }^{30}$

By using the language of male occupations for women's philanthropic work, More gives such work a status equal to men's work. The conjunction of the vocabularies of business, politics, and domesticity at the site of philanthropic discourse allowed women like More-women who did not confine their activity to the domestic sphere-to define themselves as "proper" and "feminine" even while they took an active role in political and economic activities that were usually associated with men.

The two major projects on which More's own fame as a philanthropist rested were the Cheddar Schools and the Cheap Repository Tracts. Following the domestic model, both ventures were suggested and financed by men, but carried out by women. In 1789, while visiting More at her home in Cowslip Green, More's friend and fellow Evangelical William Wilberforce returned from a picnic in the Mendip Hills appalled at the poverty and degradation of the inhabitants of that area. More's sister, Martha "Patty" More, records his reaction:

The servant, at his request, was dismissed, when immediately he began, "Miss Hannah More, something must be done for Cheddar." He then proceeded to a particular account of his day-of the inquiries he had made respecting the poor. There was no resident minister, no manufactory, nor did there appear any dawn of comfort, either temporal or spiritual. The method or possibility of assisting them was discussed until a late hour. It was at length decided in a few words by Mr. W's exclaiming, "If you will be at the trouble, I will be at the expense." (Martha More 12-13)

Hannah More responded by establishing her first Sunday Bible School, along with a School of Industry (which taught spinning and housework to girls) and a wom- 
en's Friendly Society. ${ }^{31}$ By 1791 , More and her sisters had nearly a thousand children attending their schools in ten parishes (Rodgers 144). More did not teach or work directly in the schools, but served rather as chief administrator over all of them. Seeing to the distribution of Wilberforce's financial contribution, like a wife disbursing a husband's income, More acted as a "professional" female philanthropist. ${ }^{32}$

Similarly, the Cheap Repository Tracts were also suggested by a man, but carried out by More. This time the project was suggested by Beilby Porteus, Bishop of London. Beginning with "Village Politics, by Will Chip," More began writing the series of tracts, which enjoyed phenomenal sales. "No such sale has ever been heard of in the annals of England," said one of her three publishers (Brown 135). The tracts were financed at first by members of the Clapham Sect and later by a philanthropic society that solicited subscriptions to finance the printing, although the tracts were so popular that they eventually generated a profit for their publishers (Spinney 302). Though the records of the financial dealings involved with the Cheap Repository are somewhat sketchy, it is clear that while the project was financed by others, More took an active role in the marketing, as well as the editing, which she did almost single-handedly. More's tracts, in fact, were an important and trend-setting experiment in the mass production of reading materials, something like what manufacturers like Josiah Wedgwood were doing with other consumer goods (Bradley 42)..$^{33}$

Some feminist critics have argued that because many of the projects More managed and supervised were proposed and paid for by men, she was merely serving patriarchal interests in order to gain approval from those men. ${ }^{34}$ While there is no doubt that More's projects furthered a certain kind of patriarchal interest by promoting the doctrine of separate spheres and reinforcing the primacy of women's domestic roles, it is also true that including the "profession" of philanthropy in her vision of women's sphere posed an inherent challenge to the ideology that restricted women's activities to their homes and families. Because she defined the male-oriented world of business and politics as merely a larger version of the domestic, where both men and women had critical roles, More was able to occupy a position from which she could participate prominently in that public world and still be considered an appropriately "feminine" woman. Her professional activities-administering school systems; writing, editing, and marketing books and tracts; and taking a very public role in political and religious discussions and controversiescould still be considered part of a woman's proper profession: a philanthropy that both mirrors and is an extension of the home. While this gained her personal fame and fortune, it also served as a model of what other women could do as well..$^{35}$ Women's philanthropy was so important to More's vision of "woman's mission" that she refers to it approximately 60 times in Coelebs in Search of a Wife.

Hannah More's most recent biographer, M. G. Jones, asserts that More was "a woman of far richer personality and of greater significance in the history of her time than has been commonly acknowledged" (ix). Just as her personality has been sanitized by earlier biographers, her significance as a writer and public figure to the 
history of women has been obscured by her apparently conservative attitudes toward women and the working classes. Yet More's claims for expanded opportunities for women of her own class depended precisely on those apparently conservative views. A religious paternalistic society in which the poor maintained "a just subordination" was a necessary condition for affluent women to act with authority in settings outside the home as "the underagents of God." Advocating the same kinds of rational desires and behaviors for women philanthropists that later political economists would recommend for men in the business world, More helped to ensure that middle- and upper-class women would play a central role in social and economic relations. Though she insisted on the difference between men and women, and assigned women to the domestic sphere, More used women's traditional association with charity to recast the political, economic, and social world associated with men as simply a larger version of the domestic that not only allowed, but required women's active participation. While earlier proponents of women's philanthropy, such as Mary Astell and Sarah Scott, had proposed all-female utopian societies as alternatives to the domestic sphere for upper-class women, More's conception of women's philanthropy enabled her to expand that sphere so that it could encompass alternatives. By representing women's philanthropy as not only an alternative to women's domestic role, but also a necessary and important part of that role, More not only appealed to, but helped to generate, middle- and upper-class women's desires to participate in the world outside their homes and to define themselves as something other than objects of men's desires. If More's domestic prescription for women had a lasting impact on the lives of nineteenth-century "angels in the house," her strategy of domesticating the public sphere was used by later feminists to bring the angel out of the house and into social work, higher education, paid professions, elected offices, and other important arenas for women.

\section{NOTES}

1. More's novel-cum-conduct book was extremely popular when it first appeared. Brown notes, for example, that Coelebs in Search of a Wife went through more editions and brought in more profits than Sir Walter Scott's Waverley (395n). Because of its heavy didacticism, the book's genre has always posed problems for critics. Sydney Smith, in an Edinburgh Review article, used the suggestive term "dramatic sermon" to describe More's book, in which a pious young man sets out on a search to find a perfect wife (146). More uses the voice of "Coelebs" to present numerous didactic character sketches, as well as Spectator-like essays. She was praised even by her detractors for the wit and lively observation of some of the character types she presents in Coelebs, but there is virtually no plot. Smith's term is suggestive because, if anything, the strongest part of the book is the way the characters reveal themselves through their speechessomething More undoubtedly learned to do as a popular playwright some thirty years earlier in her career.

2. For a thorough account of nineteenth-century women's involvement in such philanthropic endeavors, see Prochaska. 
3. While Kowaleski-Wallace's reading is purportedly historical, her reliance on global, ahistorical categories such as "patriarchy,"“"complicity," "nature," and various psychoanalytic terms, as well as her rather suspect attempt to psychoanalyze the historical Hannah More, is ultimately less convincing than Myers's accounts of More's influence: For instance, Kowaleski-Wallace recognizes "a kind of female empowerment" in middle-and upper-class women's philanthropic work, but her persistent stress on the way "the patriarchal system" or Evangelical men "employ" or "allow" women to further patriarchal aims denies More's (and other women's) agency in claiming, defining, and shaping both accepted female roles and their participation in important social activities such as philanthropy (56-58).

4. Gerard explains how this kind of traditional women's philanthropy coexisted with more institutionalized urban philanthropy well into the nineteenth and even twentieth centuries. For discussion of the way this tradition evolved in other countries, see McCarthy.

5. For a discussion of the bonds of deference, see Newby.

6. A particularly vituperative account of More's paternalist sympathies is Richardson's "Sentimental Journey of Hannah More."

7. Sutherland makes a similar point about the power More gives to middle-class women in the story of Mrs. Jones (38-40), as does Myers ("Tracts" 275-77). Neither, however, addresses the way in which Mrs. Jones's reform of her community contributes to the redefinition of paternalism or the desires it is expected to inspire in women readers.

8. Altick describes the methods employed for widespread distribution to the lower classes of political pamphlets, especially Paine's The Rights of Man. He also discusses the Cheap Repository Tracts, showing how More and her coworkers shrewdly "designed the tracts to look like the pamphlets they were intended to supersede" (70-75). The phenomenal sales figures for More's tracts-over two million were sold the first year-indicate that they were quite successful in achieving their aim, although it is impossible to determine exactly how many laboring people actually bought or read the tracts because many of them were sold to middle- and upper-class buyers for free distribution to the poor.

9. Olivia Smith gives a useful account of More's innovative use in The Cheap Repository Tracts of realistic techniques and simple but uncondescending language (90-94).

10. Harrison's essay on Wordsworth's "The Old Cumberland Beggar" also discusses charity as a version of a gift exchange economy. In Harrison's reading of Wordsworth's poem, the recipient of charity "does not participate fully in the gift exchange that supposedly creates the communal bond of domestic affection" because he "ostensibly returns their favors in an abstract exchange of which he is entirely unaware" (35). In the example of More's gardener, however, it is clear that her charitable recipient knowingly exchanges his gratitude and service for the material gifts conferred. While More's portrayal of the exchange of gifts also clearly reinforces "paternalistic attitudes" (34), it enlists the poor themselves in maintaining the system that (for More) benefits both them and women philanthropists, while contributing to the safety and security of the nation.

11. Cheal, in fact, claims that "the tension between market relationships and personal relationships [i.e., gift exchange] is a distinctive characteristic of social life in capitalist societies" (4). 
12. In her discussions of More's Cheap Repository Tracts, Olivia Smith notes how frequently the tracts portray poor characters who exhibit extraordinary endurance but are unable to get ahead without the intervention of charity. As Smith observes, More "wanted them to endure, but not to manage for themselves" (93). By representing the poor, however hardworking and virtuous, as still in need of charitable rescuing, More tries to ensure that philanthropists, especially women, will continue to have work to do.

13. See Laqueur's Religion and Respectability for an extended discussion of working class attitudes toward and participation in charitable schools.

14. For a summary of arguments that in a gift exchange, the "donor's rights are never extinguished" because a gift is not a commodity that can be "alienated," see Cheal (10).

15. Kowaleski-Wallace makes an important point about Evangelical women when she argues that their "supreme bodily self-discipline became the identifying mark of [their] class privilege" (74).

16. In the second quotation McKendrick is quoting Appleby (515).

17. Armstrong describes the role of husband and wife in the new household domestic economy in this way (83-88).

18. While earlier in the eighteenth century it was thought that even prostitutes could be reformed and turned into "joyful mothers of children" (Hanway xxii), by the end of the century attitudes toward "fallen women" had changed to reflect the growing emphasis on the de-sexualized "angel" as the norm for women. Such women could be helped and protected, but not returned to their former place in society (Andrew 189).

19. While Tobin and others are right that the values More is promoting are those of the emergent middle class, it is not accurate to assume that More is primarily speaking to middle-class women or that she believed aristocratic women had "forfeited to the middle classes the right to occupy supervisory roles" (Tobin 5). That argument seems reasonable if one looks mostly at the story of Mrs. Jones and the other tales addressed to the middle ranks, but Coelebs in Search of a Wife focuses almost exclusively on the gentry and aristocracy. Tobin acknowledges that Lucilla Stanley and More herself were tied to the landholding classes, but still regards them as spokeswomen for the middle classes. While More, as Tobin maintains, definitely does criticize landholders' handling of their paternal responsibilities, her aim is to reform, not replace them. The exemplary middle classes, in More's view, will join, not supplant, the upper class in governing the laboring population.

20. Interestingly, early in More's career she published a poem called "Sensibility," which is addressed to Mrs. Boscawen of the "Bas Bleu" or "Bluestocking Circle" and includes tributes to her as well as other women writers. In the poem, written before her conversion to Evangelicalism, More demonstrates her already ambivalent attitude toward sensibility - she both extols it, cautioning against a "pausing prudence" which might refuse "charity with open hand," and claims such feelings as the special prerogative of women. But she is also careful, even in this early poem, to link both sensibility and charity to religion, the "Love Divine! sole source of Charity!" (Works 1: 135-55).

21. The most obvious novelistic examples of this kind of heart-rending but pleasurable charity are Laurence Sterne's A Sentimental Journey (1768) and Henry Mackenzie's The Man 
of Feeling (1771), though most novels of sensibility portray at least a few similar scenes. An example closer to the time of More's own novel is Ann Radcliffe's Mysteries of Udolpho (1794), where the hero Valancourt gives up nearly his last franc for the pleasure of relieving a shepherd's family.

22. On women's ambitious desires, see Miller. Her essay refutes Freud's attribution of ambitious desires to men and erotic desires to women by looking for ambitious desires encoded in the "implausibilities" in women's fiction. While Miller assumes the preexistence of ambitious desires in women, my reading of More attempts to show how such desires were generated.

23. Philanthropic institutions formed especially to aid "fallen" (or potentially fallen) women such as prostitutes and female orphans were the first to rely on "ladies" to manage and supervise the inmates. Chaste ladies, it was assumed, could better teach the inmates to regulate their own sexual desires. Furthermore, using ladies prevented male philanthropists from being tempted by or threatening to the "victims" the institutions aimed to reform. One of the earliest philanthropic institutions to have women as directors, for instance, was the Dublin Magdalen Asylum for Female Penitents (Bayly 28-29).

24. See Poovey for a discussion of the paradox of modesty (22-26).

25. More was much opposed to the "epidemical mania" for accomplishments among women of "the middle station," whom she saw as "declining in usefulness" as they rose in "ill-founded pretensions to elegance" (Strictures 7: 75).

26. See Malmgreen's comments on the feminization of religion in England (2-3).

27. One of the most famous of these was Mary Astell's A Serious Proposal to the Ladies, for the Advancement of Their True and Greatest Interest. An earnest advocate of women's education, Astell proposed founding a "Monastery, or if you will ... a Religious Retirement," which would serve the double purpose of being "not only a Retreat from the World for those who desire that advantage, but likewise, an Institution and previous discipline, to fit us to do the greatest good" in the world (36). Though Astell's proposal was never actually implemented, largely because it raised fears of Popery, its arguments about the suitability of charitable work for women were influential throughout the eighteenth century. A few Anglican sisterhoods were founded during the nineteenth century, mostly under the auspices of the High Church Tractarian movement.

28. Several other critics have noticed the way More deploys the metaphor of the family as a model for social and political relations. Kowaleski-Wallace, for instance, comments on what she calls a "familial configuration" in the "new alliance between the Evangelical clergy and women" (60). While I, too, identify a familial model in the organization of Evangelical philanthropic reform projects, I would challenge Kowaleski-Wallace's exclusive focus on the "maternal" and "nurturing" role "assigned" to women in philanthropic projects by men (almost unfailingly read as father-figures). Her contention that More's settling for "maternal agency" failed to "transcend cultural stereotypes" and hence proved inadequate as a feminist strategy ignores the many ways in which this strategy of organizing the world in domestic terms proved useful to women arguing for women's advancement throughout the nineteenth and twentieth centuries (93). 
Krueger also identifies "class and gender interests striving to reconfigure social relations along the lines of a rigidly structured domestic model," but she does not connect this to philanthropy (106-7).

29. Along with More, Sarah Trimmer had been active in organizing and directing Sunday Schools; Elizabeth Fry is well known for her domestic reform work in early-nineteenth-century prisons. For other examples during the period, see Prochaska.

30. In another place, Mrs. Stanley also refers to her elder daughters as "veterans in their trade" (2: 23).

31. See Jones (151-171) and Hopkins (156-184) for an account of More's schools. The primary sources for this information are both Patty More's Mendip Annals and Hannah More's fictional account in her tract "The Sunday School" (4: 358-386).

32. Pollock describes one of many other incidents in which More provided the sympathy and the legwork, while Wilberforce and two of his friends provided money, when it was discovered that the prominent Methodist Charles Wesley's widow and unmarried daughter were in a reduced financial situation (155). Howse describes More as the "appointed agent of Wilberforce and Thornton in their philanthropic activities" (19).

33. See also McKendrick (31-33) for a discussion of new mass marketing ventures. Though he does not mention books or The Cheap Repository as an example, the project in some ways clearly fits in the same category with the "small items of household consumption" he does discuss (31).

34. See, for instance, Kowaleski-Wallace $(57,64)$.

35. More's biographers note that by the time of her death she had amassed 30,000 pounds, a considerable fortune, mostly from her prodigious literary output (Hopkins 251).

\section{WORKS CITED}

Aikin, Lucy. Correspondence of William Ellery Channing, D. D. and Lucy Aikin. Ed. Anna Letitia le Breton. London, 1874.

Altick, Richard D. The English Common Reader. Chicago: U of Chicago P, 1957.

Andrew, Donna T. Philanthropy and Police: London Charity in the Eighteenth Century. Princeton: Princeton UP, 1989.

Appleby Joyce. "Ideology and Theory: The Tension between Political and Economic Liberalism in Seventeenth-Century England." The American Historical Review 81.3 (1976): 515.

Armstrong, Nancy. Desire and Domestic Fiction: A Political History of the Novel. New York: Oxford UP, 1987.

Astell, Mary. A Serious Proposal to the Ladies, for the Advancement of Their True and Greatest Interest. 1694. 4th ed. London, 1701.

Bayly, Edward. A Sermon Preached on the Opening of the New Chapel of the Magdalen Asylum in Leeson-Street, Dublin. Dublin, 1770. 
Blau, Peter M. Exchange and Power in Social Life. New York: Wiley, 1967.

Bradley, Ian. The Call to Seriousness. New York: Macmillan, 1976.

Brown, Ford K. Fathers of the Victorians: The Age of Wilberforce. Cambridge: Cambridge UP, 1961.

Cheal, David. The Gift Economy. London: Routledge, 1988.

Clarke, W. K. Lowther. A History of the S.P.C.K. London: SPCK, 1959.

Cole, Lucinda. "(Anti) Feminist Sympathies: The Politics of Relationship in Smith, Wollstonecraft, and More." ELH 58 (1991): 107-40.

Davidoff, Leonore, and Catherine Hall. Family Fortunes: Men and Women of the English Middle Class, 1780-1850. Chicago: U of Chicago P, 1987.

Gerard, Jessica. "Lady Bountiful: Women of the Landed Classes and Rural Philanthropy." Victorian Studies 30 (1987): 183-210.

Gray, B. Kirkman. A History of English Philanthropy. London: P. S. King, 1905.

[Hanway, Jonas]. A Plan for Establishing a Charity-House, or Charity-Houses, for the Reception of Repenting Prostitutes, to be called the Magdalen Charity. London, 1758.

Harland, Marion [Mary Virginia Hawes]. Hannah More. New York: Putnam's, 1900.

Harrison, Gary. 'Wordsworth's 'The Old Cumberland Beggar': The Economy of Charity in Late Eighteenth-Century Britain." Criticism 30 (1988): 23-42.

Hopkins, Mary Alden. Hannah More and Her Circle. New York: Longmans, 1947.

Howse, Ernest Marshall. Saints in Politics: The "Clapham Sect" and the Growth of Freedom. Toronto: $\mathrm{U}$ of Toronto P, 1952.

Jones, M. G. Hannah More. Cambridge: Cambridge UP, 1952.

Kowaleski-Wallace, Elizabeth. Their Fathers' Daughters: Hannah More, Maria Edgeworth, and Patriarchal Complicity. New York: Oxford UP, 1991.

Krueger, Christine L. The Reader's Repentance: Women Preachers, Women Writers, and Nineteenth-Century Social Discourse. Chicago: U of Chicago P, 1992.

Laqueur, Thomas. Religion and Respectability: Sunday Schools and Working Class Culture 1780-1850. New Haven: Yale UP, 1976.

Malmgreen, Gail. Religion in the Lives of English Women, 1760-1930. Bloomington: Indiana UP, 1986.

Mathias, Peter. The Transformation of England. New York: Columbia UP, 1979.

Mauss, Marcel. The Gift: Forms and Functions of Exchange in Archaic Societies. Trans. Ian Cunnison. New York: Norton, 1967.

McCarthy, Kathleen D., ed. Lady Bountiful Revisited: Women, Philanthropy, and Power. New Brunswick: Rutgers UP, 1990.

McKendrick, Neil, John Brewer, and J. H. Plumb. The Birth of a Consumer Society. Bloomington: Indiana UP, 1982. 
Miller, Nancy K. "Emphasis Added: Plots and Plausibilities in Women's Fiction." PMLA 96 (1981): Rpt. in The New Feminist Criticism. Ed. Elaine Showalter. New York: Pantheon, 1985. 339-360.

More, Hannah. Coelebs in Search of a Wife: Comprehending Observations on Domestic Habits and Manners, Religion and Morals. 1808. 4th ed. 2 vols. London, 1809.

- Strictures on the Modern System of Female Education. London, 1801. Vols. 7-8 of The Works of Hannah More. 8 vols.

- The Works of Hannah More. 8 vols. London, 1801.

More, Martha. Mendip Annals. Ed. Arthur Roberts. 2nd ed. London, 1859.

Myers, Mitzi. "Hannah More's Tracts for the Times: Social Fiction and Female Ideology." Fetter'd or Free? British Women Novelists, 1670-1815. Ed. Mary Anne Schofield and Cecilia Macheski. Athens, OH: Ohio UP, 1986. 264-316.

- "Reform or Ruin: 'A Revolution in Female Manners.'" Studies in Eighteenth-Century Culture. Ed. Harry C. Payne. Madison: U of Wisconsin P, 1982. 11: 199-216.

Newby, Howard. "The Deferential Dialectic." Comparative Studies in Society and History 17 (1975): 139-164.

Owen, David. English Philanthropy 1660-1960. Cambridge, MA: Belknap P of Harvard UP, 1964.

Perkin, Harold. Origins of Modern English Society. London: Ark-Doubleday, 1969.

Pollock, John. William Wilberforce. New York: St. Martin's, 1978.

Poovey, Mary. The Proper Lady and the Woman Writer: Ideology as Style in the Works of Mary Wollstonecraft, Mary Shelley, and Jane Austen. Chicago: U of Chicago P, 1984.

Prochaska, F. K. Women and Philanthropy in Nineteenth-Century England. Oxford: Clarendon, 1980.

Richardson, William. "Sentimental Journey of Hannah More: Propagandist and Shaper of Victorian Attitudes." Revolutionary World. 11-13 (1975): 228-239.

Rodgers, Betsy. Cloak of Charity: Studies in Eighteenth-Century Philanthropy. London: Methuen, 1949.

[Scott, Sarah]. "A Gentleman on His Travels." A Description of Millenium Hall and the Country Adjacent Together with the Characters of the Inhabitants and such Historical Anecdotes and Reflections as May Excite in the Reader Proper Sentiments of Humanity, and Lead the Mind to Virtue. 1762. New York: Penguin-Virago, 1986.

Smith, Olivia. The Politics of Language 1791-1819. Oxford: Clarendon, 1984.

[Smith, Sydney]. Rev. of Coelebs in Search of a Wife, by Hannah More. Edinburgh Review 14.27 (1809): 145-151.

Spinney, G. H. "Cheap Repository Tracts: Hazard and Marshall Edition." The Library 20 (1939): 295-340. 
Sutherland, Kathryn. "Hannah More's Counter-Revolutionary Feminism." Revolution in Writing: British Literary Responses to the French Revolution. Ed. Kelvin Everest. Philadelphia: Open UP, 1991. 27-63.

Tobin, Beth Fowkes. Superintending the Poor: Charitable Ladies and Paternal Landlords in British Fiction, 1770-1860. New Haven: Yale UP, 1993. 